Article

\title{
Zinc Porphyrin-Functionalized Fullerenes for the Sensitization of Titania as a Visible-Light Active Photocatalyst: River Waters and Wastewaters Remediation
}

\author{
Elzbieta Regulska ${ }^{1, *(1)}$, Danisha Maria Rivera-Nazario ${ }^{2}$, Joanna Karpinska ${ }^{1}(0)$ \\ Marta Eliza Plonska-Brzezinska ${ }^{3, *(D)}$ and Luis Echegoyen ${ }^{2, *}$ \\ 1 Institute of Chemistry, University of Bialystok, Ciolkowskiego 1K, 15-245 Bialystok, Poland; \\ joasia@uwb.edu.pl \\ 2 Department of Chemistry, University of Texas at El Paso, 500 W. University Ave., El Paso, TX 79968, USA; \\ dmriveranazario@miners.utep.edu \\ 3 Department of Organic Chemistry, Faculty of Pharmacy with the Division of Laboratory Medicine, Medical \\ University of Bialystok, Mickiewicza 2A, 15-222 Bialystok, Poland \\ * Correspondence: e.regulska@uwb.edu.pl (E.R.); mplonska@uwb.edu.pl (M.E.P.-B.); \\ echegoyen@utep.edu (L.E.)
}

Academic Editor: Nathalie Solladié

check for updates Received: 3 February 2019; Accepted: 19 March 2019; Published: 21 March 2019

\begin{abstract}
Zinc porphyrin-functionalized fullerene [C60] derivatives have been synthesized and used to prepare titania-based composites. The electrochemical properties and HOMO and LUMO levels of the photosensitizers were determined by electrochemical measurements. Raman and IR techniques were used to study chemical groups present on the titania surface. Absorption properties of the composites were measured in the solid state by diffuse reflectance UV-Vis spectra (DRS). The zeta potential and aggregate sizes were determined using dynamic light scattering (DLS) and electrophoretic light scattering (ELS) techniques. Surface areas were estimated based on Brunauer-Emmett-Teller (BET) isotherms. The photocatalytic activity of the photocatalysts was tested using two model pollutants, phenol and methylene blue. The composite with the highest photocatalytic potential $\left(1 / \mathrm{TiO}_{2}\right)$ was used for river and wastewater remediation. The photodegradation intermediates were identified by LC-UV/Vis-MS/MS techniques.
\end{abstract}

Keywords: fullerene; photocatalyst; porphyrin; water remediation

\section{Introduction}

Since Fujishima and Honda [1] first demonstrated water splitting on titania $\left(\mathrm{TiO}_{2}\right)$ electrodes, $\mathrm{TiO}_{2}$ has attracted considerable interest in the field of heterogeneous photocatalysis. The extensive usage of this semiconductor derives from its convenient properties like stability, chemical and biological inertness, no toxicity, low price, and environmental friendliness. Nevertheless, there are some significant drawbacks of titania, which preclude it from being used as an efficient photocatalyst. One limitation is the reasonably large energy band-gap of $3.2 \mathrm{eV}$, which requires ultraviolet light for its excitation, and another is the high probability for recombination of the photogenerated holes and electrons.

For that reason, the photosensitization of titania with different chromophores has been reported [2-5]. Artificial photosynthetic systems employing porphyrin-linked fullerene derivatives have been thoroughly examined in organic photovoltaic cells (OPVs). Porphyrins [6-10] and fullerenes [11-19] have also been independently employed for the preparation of modified titania. 
Nevertheless, to our knowledge, there are no reports involving covalently linked porphyrin-fullerene dyads as photosensitizers for titania photocatalysis.

Heterogeneous photocatalysis is considered the most effective among the Advanced Oxidation Processes (AOPs), and has high potential for polluted water treatment. The development of effective treatment technologies for surfaces as well as for wastewaters is especially important in view of the increasing growth of water pollution by chemicals arising from many industrial, agricultural, and urban human activities. Photocatalytic treatment is considered the most promising technique due to its high efficiency, and is expected to replace other AOPs currently used for that purpose.

In this article, we report the synthesis of three novel zinc porphyrin-functionalized fullerenes (see Figure 1), which were used to prepare titania-based composites and applied for the photocatalytic degradation of phenol and methylene blue as model pollutants. The photocatalyst exhibiting the highest activity was used for the remediation of selected river waters and water effluents.

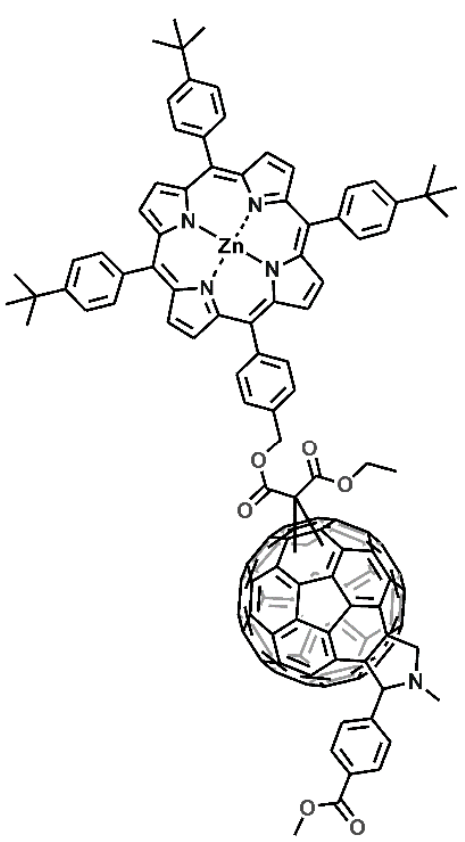

(1)

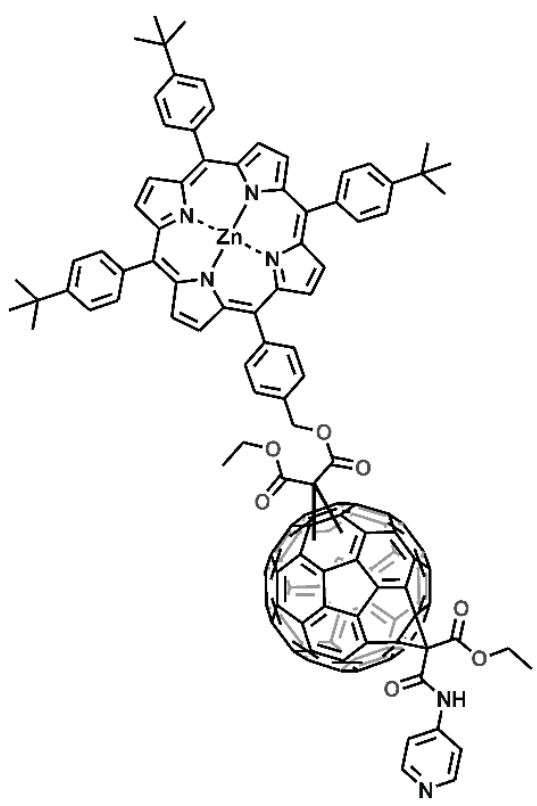

(2)

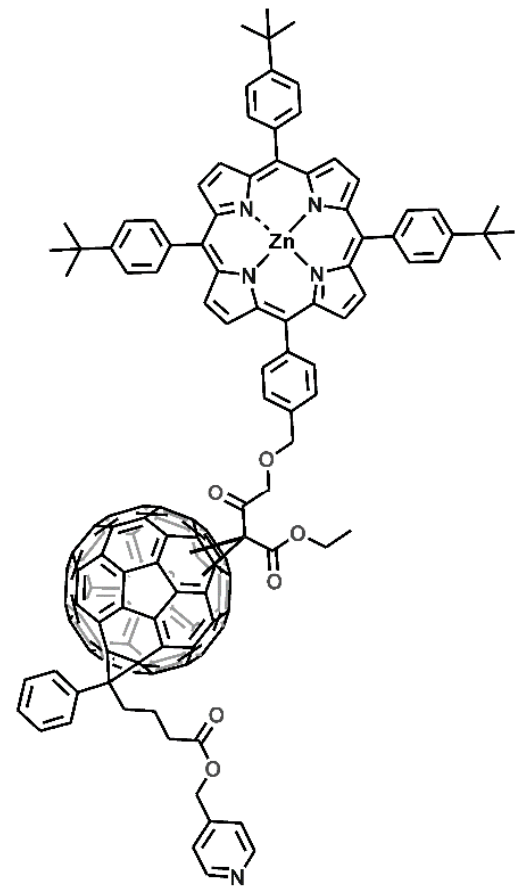

(3)

Figure 1. Structures of the fullerene derivatives: 1, 2 and 3.

\section{Results and Discussion}

\subsection{Photoelectronic Properties of the Fullerene Derivatives}

The electrochemical characterization of the synthesized fullerene derivatives was performed to examine the relation between the energies of the LUMOs of the chromophores and the conduction band of titania, and to obtain the energy band gap of each compound. The CV cycles of the compounds are presented in Figure 2. 

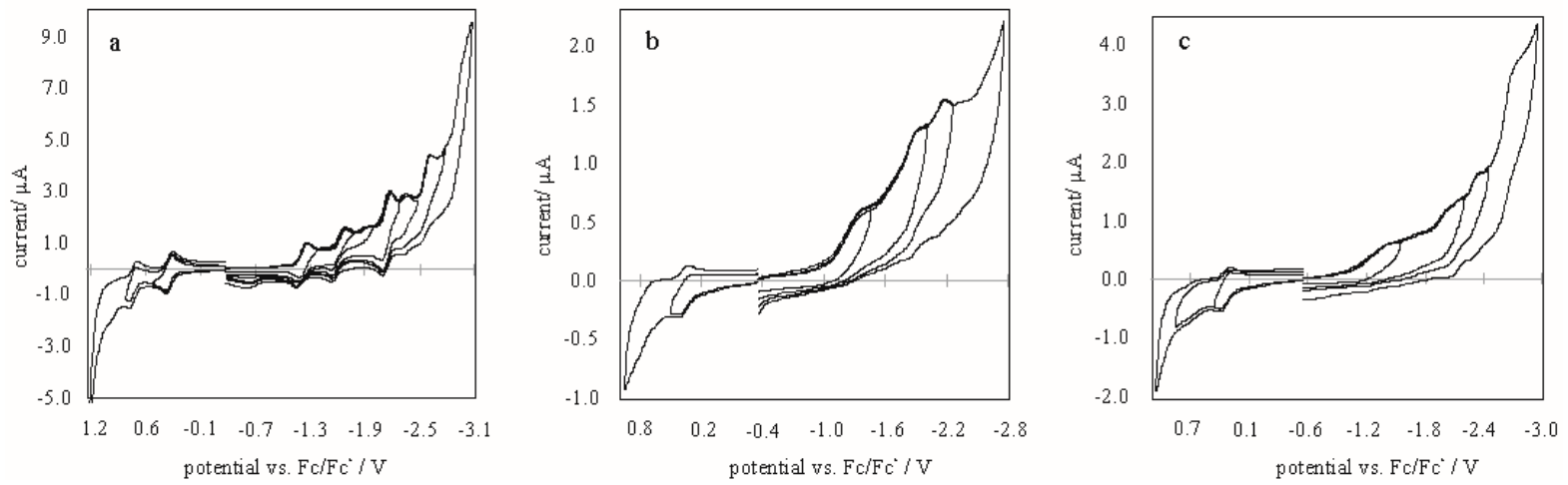

Figure 2. Cyclic voltammograms of $\mathbf{1}(\mathbf{a}), \mathbf{2}(\mathbf{b}), \mathbf{3}(\mathbf{c})$ in $\mathrm{TBAPF}_{6} /(\mathrm{MeCN}: \mathrm{Tol}=1: 4, v / v)$, at a scan rate of $50 \mathrm{mV} \cdot \mathrm{s}^{-1}$.

Two waves due to the oxidation of the porphyrin macrocycle were observed in the anodic scan associated with the formation of $\mathrm{P}^{\bullet+}$ and $\mathrm{P}^{\bullet 2+}$ [20]. Five, three, and four reduction waves were observed for the cathodic scan for 1, 2 and 3, respectively. They resulted from the reduction of porphyrin and fullerene, namely, two-electron reduction of the aromatic porphyrin ring overlapping with the reduction of the fullerene moiety. In terms of porphyrin, only the reduction of the ring is reflected on the CV curve, since the zinc(II) ion is electrochemically inactive [21]. Based on the onsets of the first oxidation and reduction peaks, the HOMO and LUMO levels of the compounds were estimated according to the following equations:

$$
\begin{aligned}
& \mathrm{E}_{\mathrm{LUMO}}=-\left(4.71-\mathrm{E}_{1 / 2, \mathrm{Fc}, \mathrm{Fc}+}+\mathrm{E}_{\text {red, onset }}\right) \\
& \mathrm{E}_{\mathrm{HOMO}}=-\left(4.71-\mathrm{E}_{1 / 2, \mathrm{Fc}, \mathrm{Fc}+}+\mathrm{E}_{\mathrm{Ox}, \text { onset }}\right)
\end{aligned}
$$

The calculated HOMO and LUMO energy values of the fullerene derivatives are presented in Figure 3. The LUMOs of the photosensitizers are all above the energy of the conduction band (CB) of $\mathrm{TiO}_{2}$, and the differences are $0.62,0.59$, and $0.51 \mathrm{eV}$ for $\mathbf{1}, \mathbf{2}$, and 3, respectively. Therefore, efficient photosensitization of $\mathrm{TiO}_{2}$ by the fullerene derivatives should be observed.

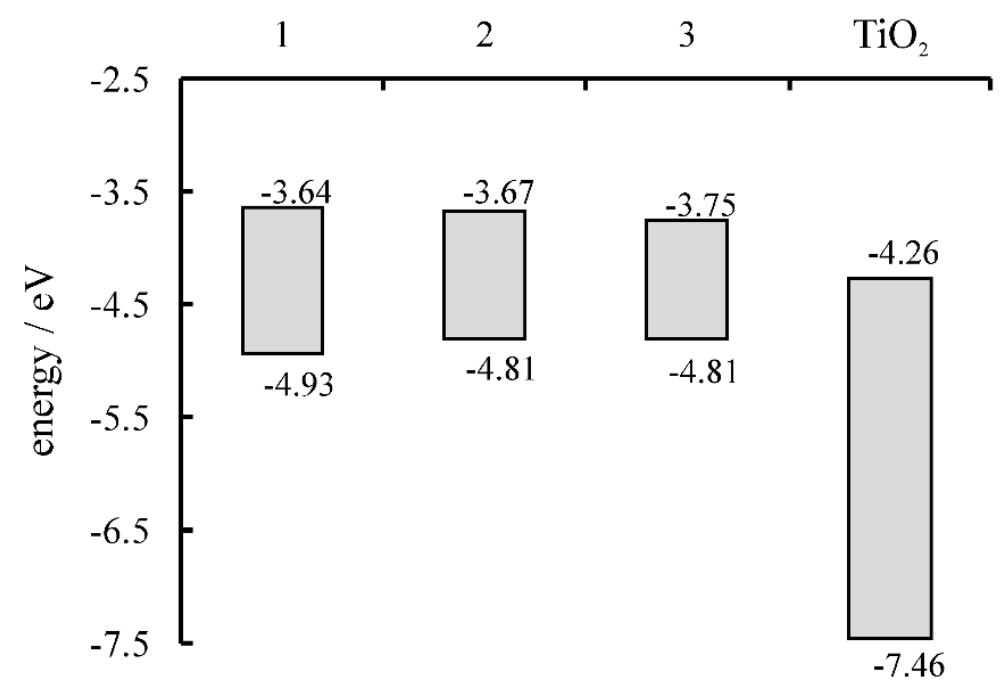

Figure 3. HOMO-LUMO energy levels for the synthesized fullerene derivatives (1-3) and $\mathrm{TiO}_{2}$. 


\subsection{Characterization of the Titania}

Raman and IR spectra of the synthesized titania are shown in Figure 4. The Raman spectrum shows broad bands at the following Raman shifts: 100-260, 380-480, 500-650, and 800-900 cm ${ }^{-1}$, which were assigned to Ti-O bending, Ti-O stretching, and Ti-O-Ti stretching vibrations, respectively [22]. A band at $1020 \mathrm{~cm}^{-1}$ was assigned to the $\mathrm{C}-\mathrm{O}$ group arising from the titanium precursor [22]. Typical bands arising from crystalline titania were not observed. Thus, the $\mathrm{TiO}_{2}$ prepared by the sol-gel synthesis was obtained in an amorphous phase. The IR spectrum (Figure 4) shows the presence of the hydroxyl groups on the oxide surface. The broad band observed in the range of $2500-3500 \mathrm{~cm}^{-1}$ results from $\mathrm{O}-\mathrm{H}$ stretching vibrations [23]. Additionally, a band around $1710 \mathrm{~cm}^{-1}$ was assigned to the $\mathrm{H}-\mathrm{OH}$ and $\mathrm{Ti}-\mathrm{OH}$ bending vibrations $[8,24]$, while the signals coming from the $\mathrm{O}-\mathrm{H}$ in-plane and out-of-plane bending vibrations were observed at $410 \mathrm{~cm}^{-1}$ and in the range of $700-800 \mathrm{~cm}^{-1}$, respectively. The presence of the hydroxyl groups on the catalyst surface is crucial for its photocatalytic performance. Therefore, the prepared oxides, despite their amorphous structure, were expected to exhibit photocatalytic activity.

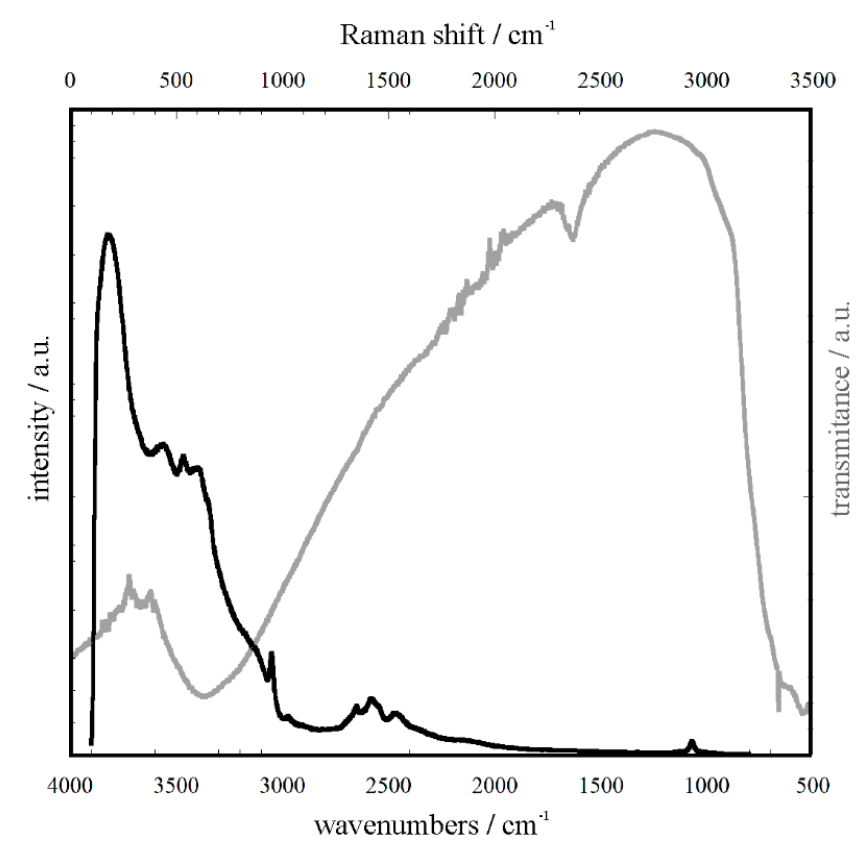

Figure 4. Raman (black line) and Attenuated Total Reflection-Fourier Transform Infra-Red (ATR-FTIR) (grey line) spectra of the synthesized titania.

\subsection{Characterization of the Composites}

The morphologies of the composites were examined by SEM microscopy and compared with the respective components, i.e., titania and fullerene derivatives $\mathbf{1}, \mathbf{2}$, and $\mathbf{3}$ (see Figure 5). The pristine titania presented a porous structure (Figure 5-1), while SEM images of fullerene derivatives showed their smooth surfaces (Figure 5-2b,3b,4b), as we have previously reported for fullerenes [25,26]. The composites $\mathrm{TiO}_{2} / \mathbf{1}, \mathrm{TiO}_{2} / \mathbf{2}$, and $\mathrm{TiO}_{2} / \mathbf{3}$ were found to form irregular bricks covered with the porous titania (Figure 5-2a,3a,4a). The introduction of the smooth fullerenes affected the specific surface areas of the composites, since the BET areas of the composites were smaller than that of the pristine titania (see Table 1). 

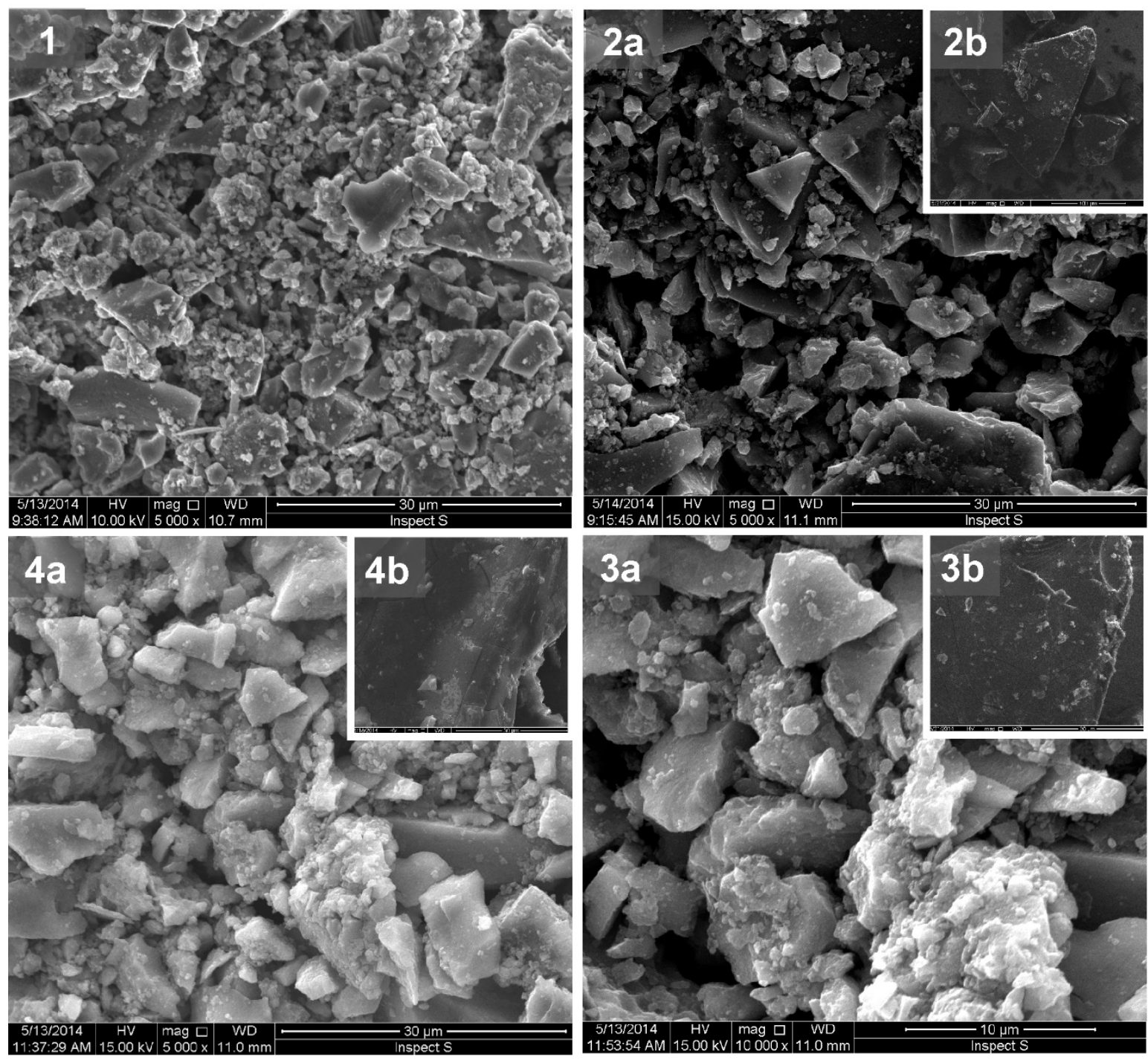

Figure 5. SEM images of titania (1), the composites $\mathrm{TiO}_{2} / \mathbf{1}(\mathbf{2 a}), \mathrm{TiO}_{2} / \mathbf{2}(\mathbf{3 a})$, and $\mathrm{TiO}_{2} / \mathbf{3}(\mathbf{4 a})$ and the fullerene derivates $1(2 b), 2(3 b)$, and $3(4 b)$.

Table 1. Brunauer-Emmett-Teller (BET) surface areas and diameters determined for titania and titania-based composites.

\begin{tabular}{ccccc}
\hline Catalyst & $\mathrm{TiO}_{\mathbf{2}}$ & $\mathrm{TiO}_{\mathbf{2}} / \mathbf{1}$ & $\mathbf{T i O}_{\mathbf{2}} / \mathbf{2}$ & $\mathbf{T i O}_{\mathbf{2}} / \mathbf{3}$ \\
\hline BET surface area $/ \mathrm{m}^{2} \cdot \mathrm{g}^{-1}$ & 269 & 178 & 151 & 158 \\
Diameter $/ \mu \mathrm{m}$ & 3.24 & 1.07 & 0.86 & 0.48 \\
\hline
\end{tabular}

The absorption spectra of the composites were compared with the spectrum of the pristine titania (Figure 6). The Soret and $\mathrm{Q}$ bands from the porphyrin macrocycles were observed for $\mathrm{TiO}_{2} / \mathbf{1}, \mathrm{TiO}_{2} / \mathbf{2}$, and $\mathrm{TiO}_{2} / 3$. They appeared within the following wavelength ranges: 390-480 and 530-680 nm for Soret and $\mathrm{Q}$ bands, respectively. The fullerene absorption band was not observed due to overlap with the strong absorption of the titania in the range of $200-380 \mathrm{~nm}$. The highest intensity of the Soret band was observed for $\mathrm{TiO}_{2} / 3$, with a maximum at $420 \mathrm{~nm}$. Moreover, a red-shift of the $\mathrm{Q}$ band was noticed for $\mathrm{TiO}_{2} / \mathbf{2}$ and $\mathrm{TiO}_{2} / \mathbf{3}$ when compared with the spectrum of $\mathrm{TiO}_{2} / \mathbf{1}$. Therefore, $\mathrm{TiO}_{2} / \mathbf{3}$ exhibits the most efficient absorption in the visible spectral range. 


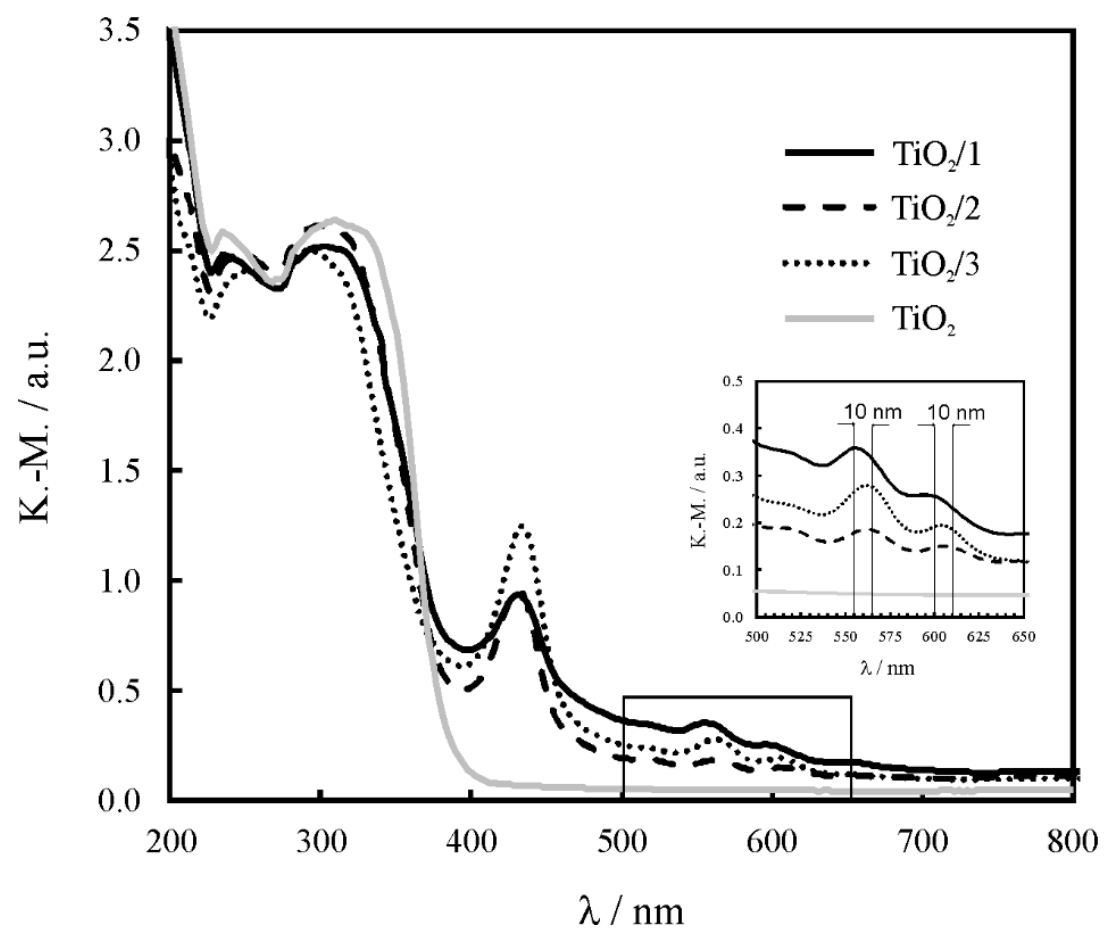

Figure 6. Kubelka-Munk plots of the titania-based composites with the fullerene derivatives: 1, 2 and 3.

The specific surface areas of the titania and the corresponding composites were determined from BET isotherms. The results (Table 1 ) for the composites were in the range of $151-178 \mathrm{~m}^{2} \cdot \mathrm{g}^{-1}$, while the surface area of the pristine semiconductor was $269 \mathrm{~m}^{2} \cdot \mathrm{g}^{-1}$. Thus, the introduction of the fullerene derivatives in the composites resulted in decreases of the BET surface areas, as expected.

The aggregate sizes of the $\mathrm{TiO}_{2}$ and the composites were determined by dynamic light scattering (DLS) measurements (see Table 1). The sizes of the catalyst aggregates may influence the kinetics of the photocatalytic degradation. It was previously reported that upon increasing the titania diameter from 0.35 to $0.66 \mu \mathrm{m}$, the photocatalytic activity of the semiconductor decreased by around 4.6 times [27]. In the present study, it was found that the diameters of the composite aggregates were 3 to 7 times lower when compared to that of the pristine titania.

Additionally, electrophoretic light scattering (ELS) studies were performed to examine the dependence of the electrophoretic potential and the $\mathrm{pH}$, in order to establish the range within which the catalysts form stable suspensions. The electric charge of the oxides in the solid state results from the presence of hydroxyl groups on their surface. Their amphoteric character results from their ability to react with both hydrogen and hydroxyl groups [27]. Bahnemann et al. [28] proposed the following notation for the chemisorption processes occurring on the surface of titania:

$$
\begin{gathered}
\mathrm{TiO}_{2}+n \mathrm{H}^{+} \rightleftarrows \mathrm{TiO}_{2} \mathrm{H}_{n}^{n+} \\
\mathrm{TiO}_{2}+n \mathrm{OH}^{-} \rightleftarrows \mathrm{TiO}_{2}(\mathrm{OH})_{n}^{n-}
\end{gathered}
$$

The high repulsion force between particles of the same charge decreases the probability of aggregation, thus increasing the stability of the sols in acidic and basic environments. The relation between the zeta potentials and the $\mathrm{pH}$ for $\mathrm{TiO}_{2}$ and $\mathrm{TiO}_{2} / 3$, is shown in Figure 7. In both cases, a similar dependence was observed. Zero-point potentials appeared at $\mathrm{pH}$ levels equal to 4.9 and 5.6 for $\mathrm{TiO}_{2}$ and $\mathrm{TiO}_{2} / 3$, respectively. For $\mathrm{TiO}_{2}$, in the $\mathrm{pH}$ range of 1.0-4.0, a $20 \mathrm{mV}$ increase of the potential was observed. The decrease of the zeta potential continued until the potential reached $-45 \mathrm{mV}$ at $\mathrm{pH}$ 9.0. Stable suspensions with $\mathrm{TiO}_{2}$ are expected to be formed only between $\mathrm{pH}$ values of 8 and 
$12 \mathrm{pH}$, while within that range, absolute values of zeta potentials exceeded $30 \mathrm{mV}$. For $\mathrm{TiO}_{2} / 3$, the zeta potential decreased with the increasing $\mathrm{pH}$ over the complete $\mathrm{pH}$ range. The absolute value of the zeta potential was higher than $30 \mathrm{mV}$ within the $\mathrm{pH}$ range of $7-12$. Therefore, under these conditions, the highest stability expected is for the $\mathrm{TiO}_{2} / 3$ aggregate. The composite particles may tend to aggregate and not be able to form stable suspensions within the $\mathrm{pH}$ range of $3-7$.

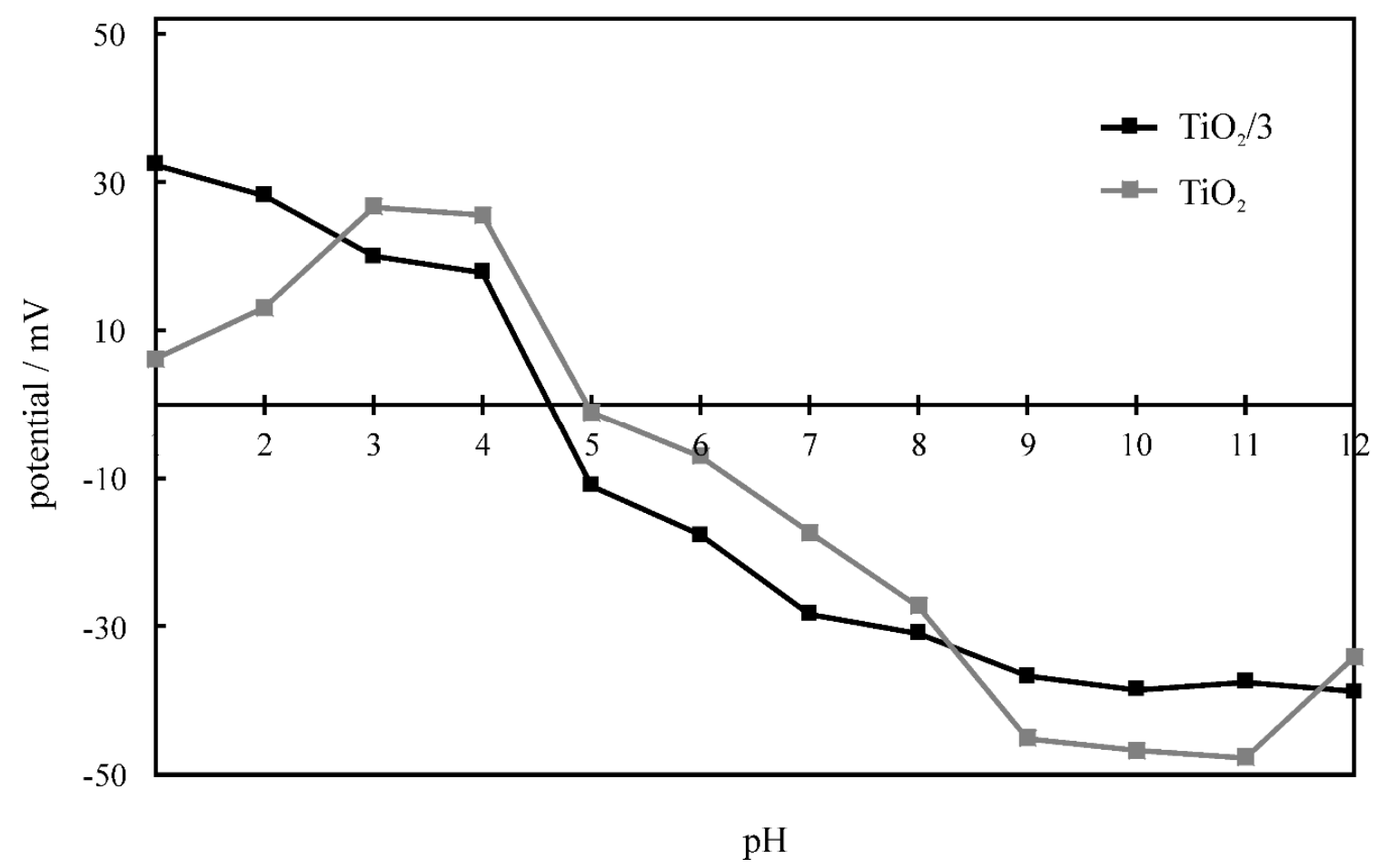

Figure 7. The efficiencies of phenol and methylene blue photocatalytic degradation in the presence of $\mathrm{TiO}_{2}$ and the given composites.

\subsection{Photocatalytic Performance}

The photocatalytic performance of the composites was tested using two model pollutants, phenol $(\mathrm{PhOH})$ and methylene blue (MB). The decreases of their relative concentrations and the efficiencies $(\eta)$ of their photocatalytic degradation in the presence of the catalysts are presented in Figure 8.
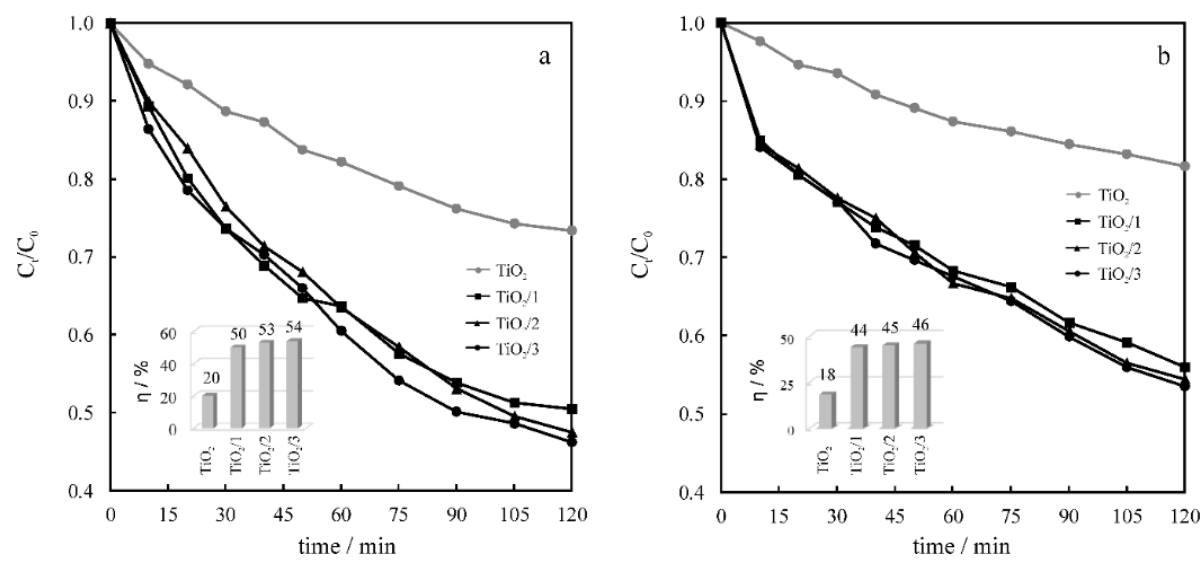

Figure 8. The decrease of phenol (a) and methylene blue (b) relative concentrations, and the efficiencies (insets) of their photocatalytic degradation in the presence of $\mathrm{TiO}_{2}$ and the given composites.

The highest $\eta$ during the degradation of $\mathrm{PhOH}$ was achieved using $\mathrm{TiO}_{2} / 3$ (54\%). However, similar values were also obtained with $\mathrm{TiO}_{2} / \mathbf{1}(50 \%)$ and $\mathrm{TiO}_{2} / 2(53 \%)$. Introduction of 3 as a 
photosensitizer enhanced the photocatalytic activity of $\mathrm{TiO}_{2}$ by nearly three times (2.7). When MB was exposed to the solar-simulated light in the presence of the composites, the degradation obtained was between $44 \%$ and $46 \%$. Again, the highest $\eta$ was observed for $\mathrm{TiO}_{2} / 3$, at 2.5 times compared with pristine $\mathrm{TiO}_{2}$. Slightly lower $\eta$ values were observed when $\mathrm{MB}$ was exposed to the radiation in the presence of the photocatalysts. This was attributed to the competitive light absorption between the catalyst and the model compound. The highest photocatalytic activity was shown by $\mathrm{TiO}_{2} / 3$ when both model pollutants were used. The proposed mechanism explaining the enhancement of the photocatalytic activity through the formation of the porphyrin-functionalized fullerene/titania composites versus pristine titania is presented in Figure 9. The improved performance of the synthesized catalysts derives from the utilization of the solar light for the excitation of the fullerene derivatives. We attribute the observed highest activity of $\mathrm{TiO}_{2} / 3$ to both the smallest difference between the LUMO of 3 and the $\mathrm{CB}$ of $\mathrm{TiO}_{2}$, and to the smallest energy band-gap of 3 among the photosensitizers.

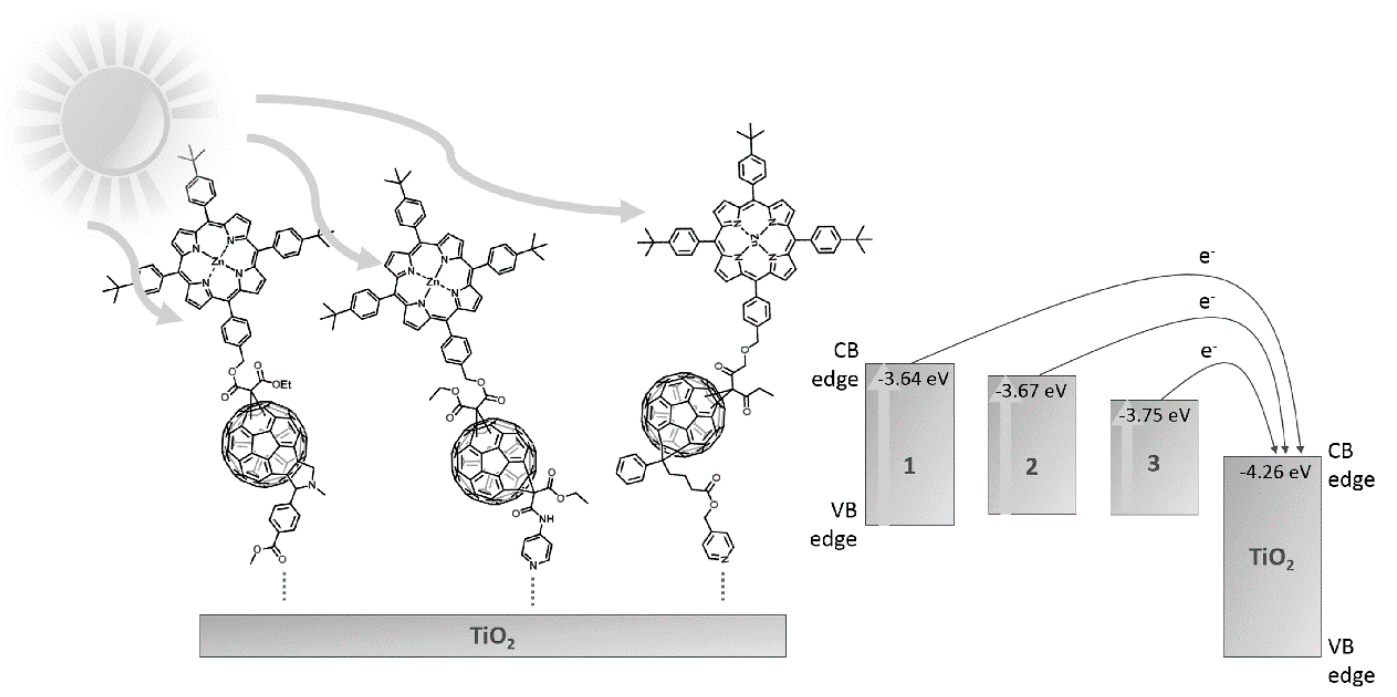

Figure 9. The proposed mechanism of the photocatalytic activity of the porphyrin-functionalized fullerenes/titania composites.

\subsection{UV-Vis Absorbance Spectra of the Photodegradation Products}

The photodegradation products of $\mathrm{PhOH}$ and $\mathrm{MB}$ during their exposure to solar light in the presence of $\mathrm{TiO}_{2} / 3$ were examined using the LC-UV-Vis-MS technique. Figure 10 depicts a chromatogram, registered after $2 \mathrm{~h}$ of $\mathrm{PhOH}$ irradiation, that shows three peaks. Based on the UV-Vis absorption and mass spectra registered at 1.71, 2.56, and $4.05 \mathrm{~min}$, the main photodegradation products were found. They were identified as 4,4'-dihydroxybiphenyl, benzoquinone, and maleic anhydride. It was also shown that under the applied conditions, complete phenol decomposition was not accomplished. Additional intermediates were identified by mass spectrometry in minor amounts (see Supporting Information).

Contrary to $\mathrm{PhOH}, \mathrm{MB}$ was completely degraded under the conditions used. In Figure 11, chromatograms of $\mathrm{MB}$ before and after its irradiation in the presence of $\mathrm{TiO}_{2} / 3$ are presented, along with the absorption spectra (Figure $11 \mathrm{a}-\mathrm{c}$ ) corresponding to the retention times at which pristine $\mathrm{MB}$ and its photodegradation intermediates were observed. The peak arising from MB did not appear in the chromatogram obtained after $2 \mathrm{~h}$ of photocatalytic treatment. However, two new peaks at 6.20 and 6.34 min were observed. Based on their absorption spectra (Figure 11b,c), it was found that the MB photodegradation intermediates absorb visible light. Even though MB was not completely decolorized, it is likely that optimal adjustment of irradiation times and higher light intensity can accomplish this in the future. A list of the identified MB photodegradation products is included in the Supporting Information. 


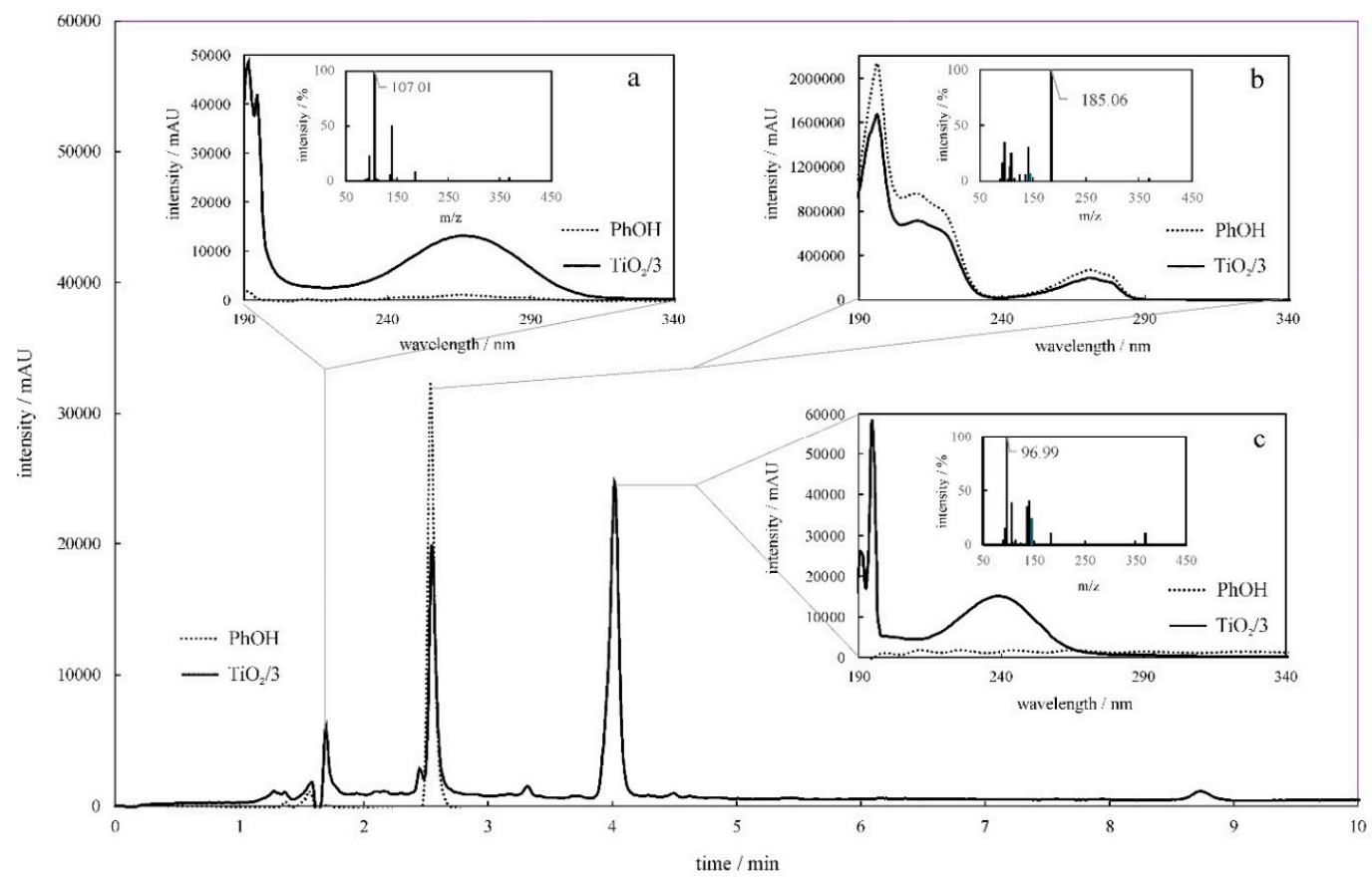

Figure 10. The chromatograms of phenol (PhOH) initial solution (dotted line) and after $2 \mathrm{~h}$ of photocatalytic treatment (solid line) with $\mathrm{TiO}_{2} / 3$, recorded at $239 \mathrm{~nm}$. Absorption spectra corresponding to the peaks are registered in the chromatograms at 1.71 (a), 2.56 (b), and $4.05 \mathrm{~min}$ (c). Insets represents mass spectra registered at respective retention times.

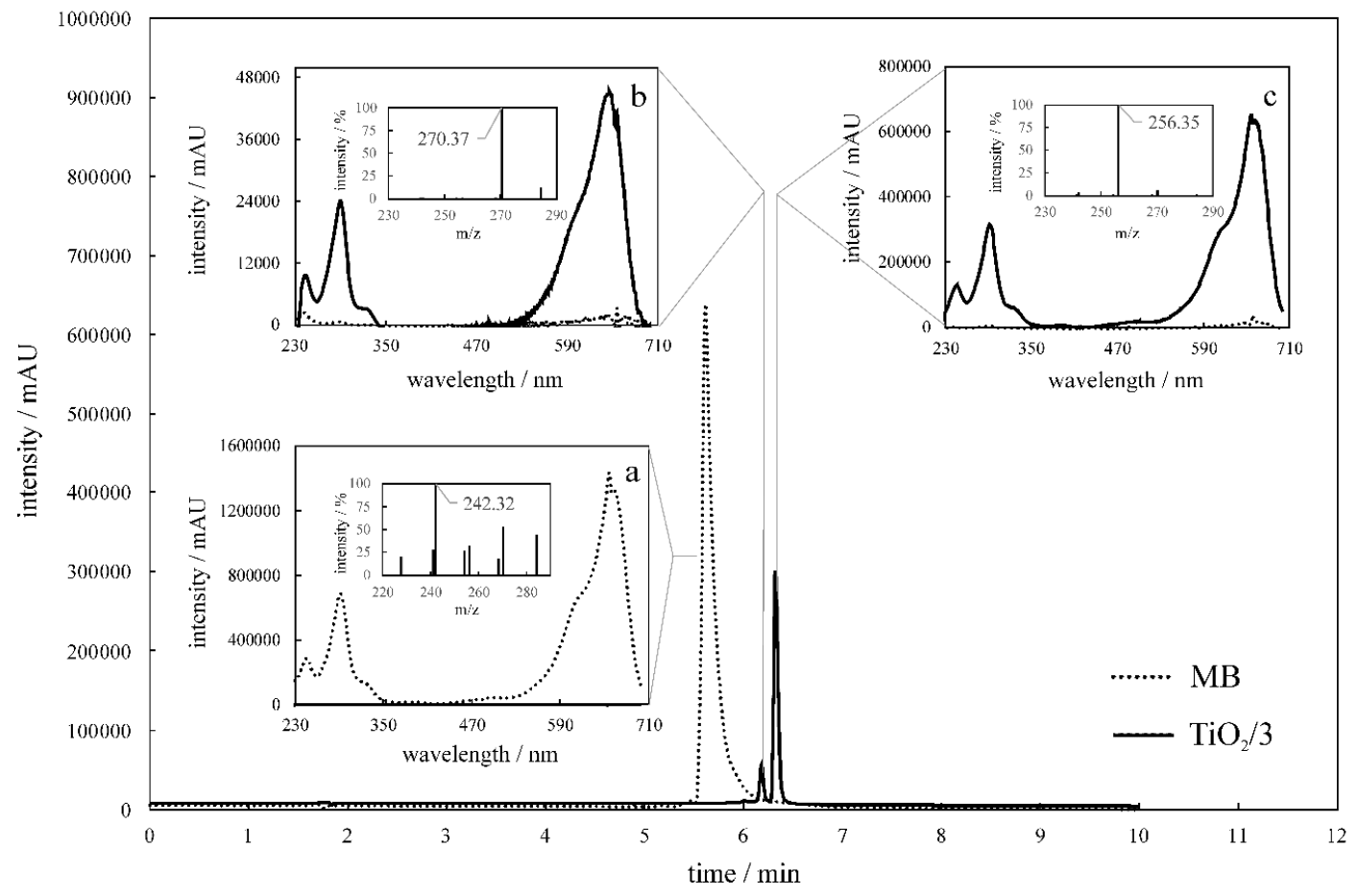

Figure 11. The chromatogram of the initial methylene blue (MB) solution (dotted line) and after $2 \mathrm{~h}$ of photocatalytic treatment (solid line) with $\mathrm{TiO}_{2} / 3$ recorded at $610 \mathrm{~nm}$. Absorption spectra corresponding to the peaks are registered in the chromatogram at 5.61 (a), 6.20 (b), and $6.34 \mathrm{~min}$ (c). Insets are the mass spectra registered at the respective retention times. 


\subsection{Photocatalytic Performance Using Natural Samples}

In order to understand the complex nature of environmental matrices, the contribution of different ions, as well as of organic compounds, needs to be considered. A series of natural matrices, including three river waters, wastewater effluent, and municipal wastewater, were used in our studies. The efficiencies of $\mathrm{PhOH}$ and $\mathrm{MB}$ photocatalytic degradation in the presence of $\mathrm{TiO}_{2}$ or $\mathrm{TiO}_{2} / 3$ are presented in Figure 12. Photocatalytic degradation conducted with the natural matrix was found to be significantly slowed down compared with the one performed in the MilliQ water. This behavior is due to the complex composition of natural samples, which leads to lower light absorption efficiencies due to competition for access to light between the catalyst and the natural water ingredients. In addition, the radicals formed during the photocatalytic reactions may react with a wide variety of substances present in the matrix, rather than resulting in the direct decomposition of the model pollutant. In this regard, the following parameters are particularly important: the oxygen content, the presence of transition metal cations, the concentration of ions responsible for water hardness, dissolved organic carbon, and the color of the sample [29]. A series of parameters was determined for both the examined river waters and wastewaters, which are presented in Tables 2 and 3, respectively. The estimated values enabled the assignment of the examined river waters to the second grade of quality [30], and for the wastewater effluents to meet the expected criteria for effluents.
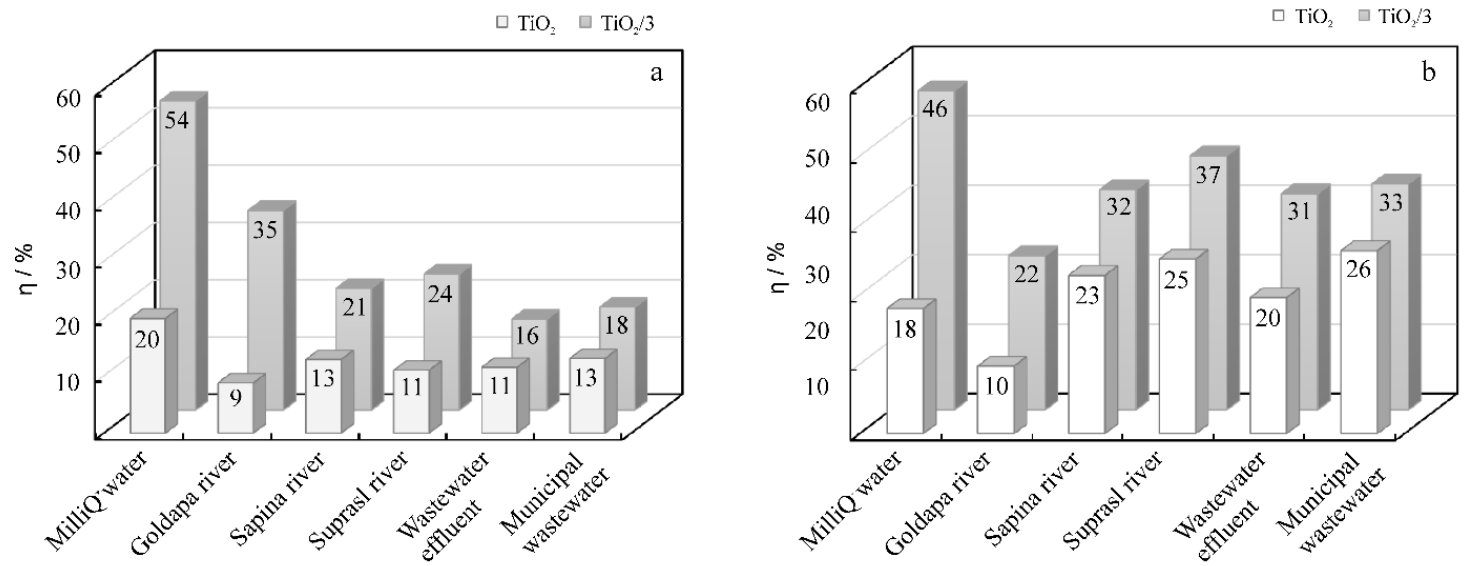

Figure 12. Efficiencies $(\eta)$ of $\mathrm{PhOH}(\mathbf{a})$ and $\mathrm{MB}(\mathbf{b})$ photocatalytic degradation in the presence of $\mathrm{TiO}_{2}$ or $\mathrm{TiO}_{2} / 3$, and the following matrices: MilliQ water, Goldapa, Sapina, and Suprasl river waters, wastewater effluent, and municipal wastewater.

Table 2. River water parameters.

\begin{tabular}{|c|c|c|c|c|c|}
\hline Parametr & Goldapa River & Sapina River & Suprasl River & $\begin{array}{c}\text { The Range of } \\
\text { Acceptable Values for } \\
\text { Rivers [30] }\end{array}$ & Norms \\
\hline $\mathrm{pH}$ & 7.8 & 7.8 & 7.5 & $6.5-8.5$ & PN-90/C-04540/01 \\
\hline Acidity $/ \mathrm{mg} \mathrm{CaCO} 3 \cdot \mathrm{L}^{-1}$ & 111.6 & 99.2 & 80.6 & nd & PN-90/C-04540/03 \\
\hline Alkalinity $/ \mathrm{mg} \mathrm{CaCO}_{3} \cdot \mathrm{L}^{-1}$ & 240.2 & 260.2 & 180.2 & $\begin{array}{l}\leq 150(\mathrm{I}) * ; \\
\leq 250(\mathrm{II}) * *\end{array}$ & PN-90/C-04540/03 \\
\hline $\mathrm{COD}^{* * * *} / \mathrm{mg} \mathrm{O}_{2} \cdot \mathrm{L}^{-1}$ & 1.9 & 2.3 & 2.3 & $\begin{array}{l}\leq 6 \text { (I); } \\
\leq 12 \text { (II) }\end{array}$ & PN-85/C-04578/02 \\
\hline Conductivity $/ \mathrm{S} \cdot \mathrm{cm}^{-1}$ & 245 & 270 & 360 & $\begin{array}{l}\leq 1000 \text { (I); } \\
\leq 1500 \text { (II) }\end{array}$ & \\
\hline Chlorine $\left(\mathrm{Cl}^{-}\right) / \mathrm{mg} \mathrm{Cl}^{-} \cdot \mathrm{L}^{-1}$ & 156.0 & 113.4 & 170.2 & $\begin{array}{l}\leq 200 \text { (I); } \\
\leq 300 \text { (II) }\end{array}$ & PN-75/C-04617/02 \\
\hline $\begin{array}{l}\text { Calcium }\left(\mathrm{Ca}^{2+}\right) / \\
\mathrm{mg} \mathrm{Ca}^{2+} \cdot \mathrm{L}^{-1}\end{array}$ & 56.1 & 74.1 & 104.2 & $\begin{array}{l}\leq 100 \text { (I); } \\
\leq 200 \text { (II) }\end{array}$ & PN-91/C-04551/01 \\
\hline $\begin{array}{l}\text { Magnesium }\left(\mathrm{Mg}^{2+}\right) / \\
\mathrm{mg} \mathrm{Mg}^{2+} \cdot \mathrm{L}^{-1}\end{array}$ & 27.3 & 16.0 & 35.3 & $\begin{array}{l}\leq 50(\text { I) } \\
\leq 100 \text { (II) }\end{array}$ & PN-71/C-04554/10 \\
\hline
\end{tabular}


Table 2. Cont

\begin{tabular}{|c|c|c|c|c|c|}
\hline Parametr & Goldapa River & Sapina River & Suprasl River & $\begin{array}{c}\text { The Range of } \\
\text { Acceptable Values for } \\
\text { Rivers [30] }\end{array}$ & Norms \\
\hline Hardness $/ \mathrm{mg} \mathrm{CaCO} 3 \cdot \mathrm{L}^{-1}$ & 207.6 & 223.6 & 347.3 & $\begin{array}{l}\leq 300 \text { (I); } \\
\leq 500 \text { (II) }\end{array}$ & PN-71/C-04554/02 \\
\hline $\begin{array}{l}\text { Dissolved oxygen } / \mathrm{mg} \\
\qquad \mathrm{O}_{2} \cdot \mathrm{L}^{-1}\end{array}$ & 0.9 & 2.2 & 1.0 & $\begin{array}{l}\geq 7 \text { (I); } \\
\geq 5 \text { (II) }\end{array}$ & ISO 5813:1983 \\
\hline Nitrate $(\mathrm{V}) / \mathrm{mg} \cdot \mathrm{L}^{-1}$ & 3.7 & 3.4 & 69.3 & $\begin{array}{l}\leq 2.2(\mathrm{I}) \\
\leq 5.0(\mathrm{II})\end{array}$ & PN-82/C-04576/08 \\
\hline Phosphate $/ \mathrm{mg} \cdot \mathrm{L}^{-1}$ & 11.5 & 7.3 & nd & $\begin{array}{l}\leq 0.20(\mathrm{I}) \\
0.31 \text { (II) }\end{array}$ & PN-88/C-04537/04 \\
\hline
\end{tabular}

${ }^{*}$ First grade of quality, ${ }^{* *}$ Second grade of quality, ${ }^{* * *}$ Chemical oxygen demand.

Table 3. Municipal wastewater and wastewater effluents parameters.

\begin{tabular}{|c|c|c|c|c|}
\hline Parameter & $\begin{array}{l}\text { Municipal } \\
\text { Wastewater }\end{array}$ & $\begin{array}{l}\text { Wastewater } \\
\text { Effluents }\end{array}$ & $\begin{array}{c}\text { The range of } \\
\text { Acceptable Values } \\
\text { for Effluents [31] }\end{array}$ & Norms \\
\hline $\mathrm{pH}$ & 10.8 & 10.7 & $6.5-9.0$ & PN-90/C-04540/01 \\
\hline Acidity $/ \mathrm{mg} \mathrm{CaCO} 3 \cdot \mathrm{L}^{-1}$ & 2.3 & 1.1 & nd & PN-90/C-04540/03 \\
\hline Alkalinity $/ \mathrm{mg} \mathrm{CaCO}{ }_{3} \cdot \mathrm{L}^{-1}$ & 580.0 & 285.0 & $150-350$ & PN-90/C-04540/03 \\
\hline $\mathrm{COD} / \mathrm{mg} \mathrm{O}_{2} \cdot \mathrm{L}^{-1}$ & 89.8 & 36.7 & $<125$ & PN-85/C-04578/02 \\
\hline Conductivity $/ \mathrm{S} \cdot \mathrm{cm}^{-1}$ & 8500 & 7000 & nd & \\
\hline Chlorine $\left(\mathrm{Cl}^{-}\right) / \mathrm{mg} \mathrm{Cl}^{-} \cdot \mathrm{L}^{-1}$ & 368.7 & 326.1 & $<1000$ & PN-75/C-04617/02 \\
\hline Calcium $\left(\mathrm{Ca}^{2+}\right) / \mathrm{mg} \mathrm{Ca}^{2+} \cdot \mathrm{L}^{-1}$ & 78.6 & 86.7 & nd & PN-91/C-04551/01 \\
\hline $\begin{array}{c}\text { Magnesium }\left(\mathrm{Mg}^{2+}\right) / \mathrm{mg} \\
\mathrm{Mg}^{2+} \cdot \mathrm{L}^{-1}\end{array}$ & 41.7 & 17.6 & $>300$ & PN-71/C-04554/10 \\
\hline Hardness $/ \mathrm{mg} \mathrm{CaCO} 3 \cdot \mathrm{L}^{-1}$ & 300.2 & 260.2 & nd & PN-71/C-04554/02 \\
\hline Dissolved oxygen $/ \mathrm{mg} \mathrm{O}_{2} \cdot \mathrm{L}^{-1}$ & nd & 1.4 & nd & ISO 5813:1983 \\
\hline Nitrate $(\mathrm{V}) / \mathrm{mg} \cdot \mathrm{L}^{-1}$ & 1226.3 & 45.0 & $<30$ & PN-82/C-04576/08 \\
\hline Phosphate $/ \mathrm{mg} \cdot \mathrm{L}^{-1}$ & 3418.5 & 18.1 & nd & PN-88/C-04537/04 \\
\hline
\end{tabular}

Different river waters affected the decomposition of the model pollutants differently. When $\mathrm{PhOH}$ was subjected to photocatalytic degradation with $\mathrm{TiO}_{2} / 3$, the smallest decrease of $\eta$ was observed in Goldapa river water (35\%) when compared to the $\eta$ obtained in MilliQ water (54\%). However, MB decomposition was found to decrease the least in Suprasl river water (from $46 \%$ to $37 \%$ ). We found that the series of parameters, including concentration of chlorine, calcium, magnesium, and nitrate ions, along with hardness and conductivity, were found to be the highest in Suprasl river waters. However, some of the species exhibit both positive and negative effects on photodegradation.

The total hardness of the water is a factor which negatively influences the performance of the photocatalytic processes. This parameter is related to the content of carbonate and bicarbonate ions, which were estimated to be the highest for the Suprasl river. These anions react with the hydroxyl radicals to generate other less reactive radical species according to the following chemical equations:

$$
\begin{aligned}
& \mathrm{CO}_{3}{ }^{2-}+\mathrm{HO}^{\bullet} \rightarrow \mathrm{CO}_{3}^{\bullet-}+\mathrm{HO}^{\bullet-} \\
& \mathrm{HCO}_{3}{ }^{2-}+\mathrm{HO}^{\bullet} \rightarrow \mathrm{CO}_{3}^{\bullet-}+\mathrm{H}_{2} \mathrm{O}
\end{aligned}
$$

It is generally believed that metal cations which are present in only one oxidation state do not affect the photocatalytic decomposition either positively or negatively. However, it was shown that the process of photocatalytic degradation can be accelerated in the presence of calcium ions. Mariquit et al. [32] showed that calcium cations support the adsorption of humic acid, thus facilitating photocatalytic oxidation. Furthermore, Yiang et al. [33], while examining typical organic pollutant 1-methylimidazole-2-thiol, indicated a faster photocatalytic degradation of the compound after the introduction of calcium ions. This parameter was the highest in the Suprasl river as well. 
On the other hand, oxygen participates in the processes described below, being a source of the oxygen radicals. It can be adsorbed on the catalyst's surface and can undergo reactions with the participation of the conduction band of $\mathrm{TiO}_{2}$ [33]:

$$
\begin{gathered}
\mathrm{e}^{-}+\mathrm{O}_{2} \rightarrow \mathrm{O}_{2}^{-}(\mathrm{ad}) \\
\mathrm{O}_{2}^{-}(\mathrm{ad})+\mathrm{H}^{+} \rightarrow \mathrm{HO}_{2}{ }^{\bullet}
\end{gathered}
$$

The valence band of titania delivers other active forms of oxygen, like $\mathrm{HO}^{\bullet}$ and $\bullet$, which results from the presented equations:

$$
\begin{gathered}
\mathrm{h}^{+}+\mathrm{H}_{2} \mathrm{O} \rightarrow \mathrm{HO}^{\bullet}(\mathrm{ad})+\mathrm{H}^{+} \\
\mathrm{h}^{+}+\mathrm{O}_{2}^{-}(\mathrm{ad}) \rightarrow 2^{\bullet} \mathrm{O}(\mathrm{ad})
\end{gathered}
$$

All of the oxygen forms, like $\mathrm{O}_{2}{ }^{-}, \mathrm{HO}^{\bullet}, \mathrm{HO}_{2}{ }^{\bullet}$, and ${ }^{\bullet} \mathrm{O}$, likely participate in the reactions leading to the degradation of the organic matter [34]. Dissolved oxygen was found to be the highest in the Sapina river, but this was not the matrix in which photodegradation was the most efficient.

The yield of the photocatalytic degradation in the presence of a river water sample may also be higher than in deionized water. Both rivers and wastewaters contain chromophores, which may also be involved in photochemical reactions leading to the formation of reactive compounds, which can initiate the decomposition of the model pollutants [35]. This was observed when MB solutions prepared in both rivers and wastewaters were irradiated in the presence of $\mathrm{TiO}_{2}$ (Figure 12b). It is believed that the presence of colored dissolved organic matter (CDOM) is responsible for the formation of singlet oxygen ${ }^{1} \mathrm{O}_{2}$ and triplet excited states ${ }^{3} \mathrm{CDOM}^{*}$. These forms may be even more important than the hydroxyl radical $\mathrm{HO}^{\bullet}$ in the photodegradation processes. CDOM exposed to sunlight undergoes the following reactions [36]:

$$
\begin{aligned}
\mathrm{CDOM}+\mathrm{hv} & \rightarrow{ }^{1} \mathrm{CDOM}^{*} \\
{ }^{1} \mathrm{CDOM}^{*} & \rightarrow{ }^{3} \mathrm{CDOM}^{*} \\
{ }^{3} \mathrm{CDOM}^{*} & \rightarrow \mathrm{CDOM} \\
{ }^{3} \mathrm{CDOM}^{*}+\mathrm{O}_{2} & \rightarrow \mathrm{CDOM}+\mathrm{O}_{2} \\
{ }^{3} \mathrm{CDOM}^{*}+\mathrm{O}_{2} & \rightarrow \mathrm{CDOM}+{ }^{1} \mathrm{O}_{2} \\
{ }^{3} \mathrm{CDOM}^{*}+\mathrm{P} & \rightarrow \mathrm{CDOM}^{\bullet-}+\mathrm{P}^{\bullet+} \\
\mathrm{CDOM}^{\bullet-}+\mathrm{O}_{2} & \rightarrow \mathrm{CDOM}+\mathrm{O}_{2}{ }^{\bullet+} \\
{ }^{1} \mathrm{O}_{2} & \rightarrow \mathrm{O}_{2} \\
{ }^{1} \mathrm{O}_{2}+\mathrm{P} & \rightarrow \mathrm{P}_{\mathrm{ox}}
\end{aligned}
$$

where $P$ is phenol or its derivatives.

Photocatalytic degradations in environmental matrices are very complex processes. It is really difficult, if not impossible, to predict the influence of all of the ingredients of a natural matrix on the photodegradation yields. In the presented studies, the same photodegradation products of both model compounds were identified using MilliQ water and all of the environmental matrices as reaction mediums (Supporting Information).

\section{Experimental}

\subsection{Methods}

${ }^{1}$ H-NMR spectra were recorded on a JEOL ECA 600 NMR spectrometer (JEOL Ltd., Peabody, MA, USA) at room temperature using $\mathrm{CDCl}_{3}$ or $\mathrm{CDCl}_{3}: \mathrm{CS}_{2}$ as solvents. Mass spectra were obtained using a Bruker microFlex MALDI-TOF LRF spectrometer (Billerica, MA, USA) on reflector positive mode, using 
1,8,9-trihydroxyanthracene or trans-2-[3-(4-tert-Butylphenyl)-2-methyl-2-propenylidene]malononitrile as the matrix.

The Attenuated Total Reflection-Fourier Transform Infra-Red (ATR-FTIR) (Thermo Scientific, Waltham, MA, USA) spectra $\left(500-3200 \mathrm{~cm}^{-1}\right)$ were obtained using a Nicolet Model 6700 FT-IR spectrometer with a DTGS detector. The crystal-diamond spectra were obtained with $4 \mathrm{~cm}^{-1}$ resolution, and 32 scans for each sample spectrum were obtained. Diffuse reflectance UV-Vis spectra (DRS) were recorded on a Jasco V-30 UV-Vis/NIR spectrophotometer equipped with an integrating sphere $60 \mathrm{~mm}$ in diameter, using $\mathrm{BaSO}_{4}$ as a reference.

Raman spectra were collected using the Renishaw Raman InVia (Renishaw, New Mills, UK) Microscope equipped with a high sensitivity ultra-low noise CCD detector. The radiation from a high-power diode laser (Renishaw, New Mills, UK) $(785 \mathrm{~nm})$ was used as the excitation source. The laser power and accumulation of scans were dependent upon the sample. Spectra were recorded using $\times 50$ objective with $10 \mathrm{~s}$ exposure time. The instrument was calibrated using an internal silicon standard $\left(521 \mathrm{~cm}^{-1}\right)$.

The sizes of the composite aggregates and zeta potentials were assessed using a NanoPlus-3 zeta /nano particle analyzer (Micromeritics Instrument Corporation, Norcross, GA, USA) for aqueous solutions. The sizes of the aggregates was determined based on dynamic light scattering (DLS) measurements for solutions of $\mathrm{pH} 7$, while the zeta potentials were determined based on electrophoretic light scattering (ELS) measurements for solutions within $\mathrm{pH}$ range 1-14. The specific surface areas were measured using low-temperature nitrogen adsorption $(80 \mathrm{~K})$ with an ASAP 2020 (Micromeritics Instrument Corporation, Norcross, GA, USA) instrument. Prior to the measurements, samples were out-gassed under vacuum at $393 \mathrm{~K}$ for $12 \mathrm{~h}$. The specific surface areas were determined using the Brunauer-Emmett-Teller (BET) method.

Electrochemical measurements were performed in a mixture of MeCN:Tol $=1: 4(v / v)$. Tetrabutylammonium hexafluorophosphate $\left(\mathrm{TBAPF}_{6}\right)$ was added as the supporting electrolyte after recrystallization from ethanol. Cyclic voltammetry $(\mathrm{CV})$ experiments were performed under an argon atmosphere at room temperature, using a CH Instrument potentiostat (CHI-440B) (Metrohm AG, Herisau, Switzerland) at a scan rate of $100 \mathrm{mV} \cdot \mathrm{s}^{-1}$. A standard three-electrode set up, consisting of a glassy carbon working electrode (ALS Co., Ltd., $1 \mathrm{~mm} \mathrm{ID),} \mathrm{a} \mathrm{platinum} \mathrm{wire} \mathrm{(1.0} \mathrm{mm,} \mathrm{Aldrich)} \mathrm{as}$ a counter electrode, and a silver wire $(1.0 \mathrm{~mm}$, Aldrich) as a pseudoreference electrode, was used. The redox couple of ferrocene/ferrocenium $\left(\mathrm{Fc} / \mathrm{Fc}^{+}\right)$was used as an internal reference to measure the potentials.

The photocatalytic degradation experiments were investigated in a $50 \mathrm{~mL}$ glass cell. The reaction mixture consisted of $20 \mathrm{~mL}$ of the model pollutant (phenol (PhOH, $10^{-4} \mathrm{~mol} \cdot \mathrm{L}^{-1}$ ) or methylene blue $\left(\mathrm{MB}, 8 \times 10^{-5} \mathrm{~mol} \cdot \mathrm{L}^{-1}\right)$, aqueous solution, and a photocatalyst $\left(1.5 \mathrm{~g} \cdot \mathrm{L}^{-1}\right)$. Before the $\mathrm{PhOH} / \mathrm{MB}$ photodegradation studies, adsorption experiments were carried out. The suspension of the model pollutant and the appropriate photocatalyst was kept in the dark while stirring for $1 \mathrm{~h}$ to attain equilibrium. To monitor the progress of the degradation during the irradiation $(2 \mathrm{~h})$, samples were taken and centrifuged every $15 \mathrm{~min}$, and the supernatant was analyzed using UV-Vis spectroscopy. The UV-Vis spectra were recorded with a HITACHI U-2800A UV-Vis spectrophotometer equipped with a double monochromator and a single beam optical system $(190-700 \mathrm{~nm})$. A SUNTEST CPS+ (ATLAS, USA) solar simulator apparatus, emitting irradiation in the range of $380-700 \mathrm{~nm}$, was used to perform photocatalytic degradation experiments. All experiments were repeated three times, and the presented results reflect the averaged data. The photon flux of solar-simulated radiation was equal to $2.32 \times 10^{-6}$ Einstein $\mathrm{s}^{-1}$ for $250 \mathrm{~W} \mathrm{~m}^{-2}$. Identification of the model pollutant photodegradation products was performed using a Shimadzu Nexera ultra high-performance liquid chromatograph with a photodiode-array detector (Shimadzu Corporation, Kyoto, Japan) and a triple quadrupole mass spectrometer (Shimadzu LCMS-8040) (Shimadzu Corporation, Kyoto, Japan) equipped with an electrospray ionization (ESI) interface. 


\subsection{Synthesis of Fullerene Derivatives}

Fullerene derivatives 1, 2, and 3 were synthesized via a Bingel-Hirsch reaction. General procedure: 1 eqv. of the porphyrin malonate 8 (see Supplementary Materials) was reacted with 1.2 eqv. of the fullerene $\mathrm{C}_{60}$ derivative $\left(\mathbf{9}, \mathbf{1 3}\right.$, or 14; see Supporting Information) in the presence of $\mathrm{CBr}_{4}$ (1.1 eqv.) and upon addition of 1,8-diazabicyclo[5.4.0]undec-7-ene (DBU) (1.2 eqv.). The reaction was completed within $3 \mathrm{~h}$. Compounds 1, 2, and $\mathbf{3}$ were isolated through the column chromatography as a mixture of isomers. For detailed procedures, see Supporting Information.

\subsection{Synthesis of Titania}

$2 \mathrm{~mL}$ of titanium isopropoxide (TIPT) was dissolved in $5 \mathrm{~mL}$ of anhydrous ethanol with $0.5 \mathrm{~mL}$ of glacial acetic acid. After $30 \mathrm{~min}$ of stirring, the prepared solution was added dropwise to $5 \mathrm{~mL}$ of $5 \%$ sodium dodecyl sulfate (SDS) solution. The obtained mixture was left for $72 \mathrm{~h}$ under stirring. The prepared gel was washed 3 times with ethanol and water, whereupon it was evaporated under reduced pressure. The obtained powder was dried by placing in the oven $\left(120^{\circ} \mathrm{C}\right)$ for $24 \mathrm{~h}$.

\subsection{Synthesis of Composites}

$0.018 \mathrm{~g}$ of $\mathbf{1}, \mathbf{2}$, or 3 were placed in a round-bottom flask with $5 \mathrm{~mL}$ of $\mathrm{CHCl}_{3}$ and $5 \mathrm{~mL}$ of $5 \%$ aqueous SDS solution. The obtained mixture was sonicated for $12 \mathrm{~h}$ (solution A). Independently, an ethanolic $(20 \mathrm{~mL})$ solution of TIPT $(666 \mu \mathrm{L})$ and glacial acetic acid $(1 \mathrm{~mL})$ (solution B) was prepared. Solution B was left under stirring for $30 \mathrm{~min}$, whereupon it was added dropwise to solution A. The mixture of A and B was placed in a round-bottom flask and stirred for $2 \mathrm{~h}$. The obtained gel was washed 3 times with ethanol and water, whereupon it was evaporated under reduced pressure. The obtained powder was dried by placing in the oven $\left(120^{\circ} \mathrm{C}\right)$ for $24 \mathrm{~h}$.

\section{Conclusions}

Three novel fullerene derivatives covalently linked to a zinc porphyrin were synthesized and applied for the sensitization of titania. This paper represents the first report of the application of porphyrin-functionalized fullerene/titania composites as photocatalysts. It was found that the LUMO levels of the modified fullerenes are appropriate for proper electron injection into the conduction band of titania. Compound 3, which exhibits the smallest energy difference with respect to the $\mathrm{CB}$ of $\mathrm{TiO}_{2}$, was the most active catalyst. The photocatalytic activities of the composites were tested against $\mathrm{MB}$ and $\mathrm{PhOH}$ in aqueous solutions as well as in a series of environmental matrices. The photocatalytic activities of all of the composites were comparable. Nevertheless, the highest photodegradation efficiency was observed for $\mathrm{TiO}_{2} / 3$. It was shown that it presents photocatalytic activity in all of the examined river waters, along with municipal wastewater and wastewater effluents. It was observed that it can form stable suspensions in solutions over a $\mathrm{pH}$ range of 7-12. Therefore, it can be used for both river and wastewater remediation, since rivers and wastewaters show neutral and basic $\mathrm{pH}$ levels, respectively. It should also be stressed that both colorless and colored substances, like $\mathrm{PhOH}$ and $\mathrm{MB}$, undergo degradation in the presence of the composites. Therefore, it can be assumed that they could be used not only for remediation of rivers and municipal wastewaters, but also of industrial wastewaters. In particular, the textile industry releases significant amounts of dyes, which are difficult to remediate. Accordingly, we believe that the results presented here show potential applications for the decontamination of a series of complex environmental and industrial matrices, using solar light as an irradiation source. 
Supplementary Materials: The following are available online at http:/ /www.mdpi.com/1420-3049/24/6/1118/ s1, Figure S1: Synthetic route to porphyrin (8): (i) $\mathrm{MeOH}, \mathrm{HCl}, 65^{\circ} \mathrm{C}$, (ii) pyrrole, 4-tert-butyl benzaldehyde, TFA, $\mathrm{DDQ}, \mathrm{CHCl}_{3}$, (iii) $\mathrm{Zn}(\mathrm{OA})_{2}, \mathrm{CHCl}_{3}$, (iv) $\mathrm{LiALH}_{4}, \mathrm{THF}$, (v) TEA, ethyl malonyl chloride, $\mathrm{THF}, \mathrm{CH}_{2} \mathrm{Cl}_{2} ;$ Figure S2: Synthetic route to fullerene (1): (i) (4), sarcosine, $o$-DCB, $180{ }^{\circ} \mathrm{C}$, (ii) (8), DBU, $\mathrm{CH}_{2} \mathrm{Cl}_{2}$, Tol; Figure S3: Synthetic route to fullerene (2): (i) TEA, $\mathrm{CH}_{2} \mathrm{Cl}_{2}$, (ii) $\mathrm{C}_{60}, \mathrm{CBr}_{4}, \mathrm{DBU}, \mathrm{Tol}, \mathrm{CH}_{2} \mathrm{Cl}_{2}$, (iii) (8), $\mathrm{DBU}, \mathrm{CH}_{2} \mathrm{Cl}_{2}$, Tol; Figure S4: Synthetic route to fullerene (3): (i) $\mathrm{HCl}, \mathrm{MeOH}, 65^{\circ} \mathrm{C}$, (ii) $\mathrm{TsNHNH}_{2}, \mathrm{MeOH}, 65^{\circ} \mathrm{C}$, (iii) $\mathrm{C}_{60}, \mathrm{NaOMe}$, pyridine, $o$-DCB, $180{ }^{\circ} \mathrm{C}$, (iv) (8), DBU, $\mathrm{CH}_{2} \mathrm{Cl}_{2}$, Tol; Figure S5: PXRD images of the as-synthesized titania (a) and the annealed at $450{ }^{\circ} \mathrm{C}(\mathrm{b})$; Table S1: List of identified compounds obtained in the photocatalytic degradation of $\mathrm{PhOH}$; Table S2: List of identified compounds obtained in the photocatalytic degradation of MB.

Author Contributions: Investigation, E.R. and D.M.R.-N.; Writing original draft, E.R.; Editing, M.E.P.-B., L.E. and J.K.; Supervision, M.E.P.-B. and L.E.

Funding: E.R. thanks the National Science Centre, Poland (projects: 2012/05/N/ST5/01479 and 2014/12/T/ST5/00118). L.E. thanks the Robert A. Welch Foundation for an endowed chair, grant \#AH-0033, and the US NSF, grants: PREM program (DMR-1205302) and CHE-1801317. LC-MS, porosimeter, IR and Raman spectrometers, UV-Vis/NIR spectrophotometer, and zeta/nano particle analyzer were funded by EU, as part of the Operational Programme Development of Eastern Poland, projects Nr POPW.01.03.00-20-034/09-00 and POPW.01.03.00-20-004/11-00.

Conflicts of Interest: The authors declare no conflict of interest.

\section{References and Notes}

1. Fujishima, A.; Honda, K. Photolysis-decomposition of water at the surface of an irradiated semiconductor. Nature 1972, 238, 37-38. [CrossRef] [PubMed]

2. Savinkina, E.; Obolenskaya, L.; Kuzmicheva, G. Efficiency of sensitizing nano-titania with organic dyes and peroxo complexes. Appl. Nanosci. 2015, 5, 125-133. [CrossRef]

3. Guarisco, C.; Palmisano, G.; Calogero, G.; Ciriminna, R.; di Marco, G.; Loddo, V.; Pagliaro, M.; Parrino, F. Visible-light driven oxidation of gaseous aliphatic alcohols to the corresponding carbonyls via $\mathrm{TiO}_{2}$ sensitized by a perylene derivative. Environ. Sci. Pollut. Res. 2014, 21, 11135-11141. [CrossRef] [PubMed]

4. Rao, V.G.; Dhital, B.; He, Y.; Lu, H.P. Single-Molecule Interfacial Electron Transfer Dynamics of Porphyrin on $\mathrm{TiO}_{2}$ Nanoparticles: Dissecting the Complex Electronic Coupling Dependent Dynamics. J. Phys. Chem. C 2014, 118, 20209-20221. [CrossRef]

5. Machado, A.E.H.; França, M.D.; Velani, V.; Magnino, G.A.; Velani, H.M.M.; Freitas, F.S.; Müller, P.S.; Sattler, C.; Schmücker, M. Characterization and Evaluation of the Efficiency of $\mathrm{TiO}_{2} /$ Zinc Phthalocyanine Nanocomposites as Photocatalysts for Wastewater Treatment Using Solar Irradiation. Int. J. Photoenergy 2008, 2008, 482373. [CrossRef]

6. Ardo, S.; Achey, D.; Morris, A.J.; Abrahamsson, M.; Meyer, G.J. Non-Nernstian Two-Electron Transfer Photocatalysis at Metalloporphyrin-TiO ${ }_{2}$ Interfaces. J. Am. Chem. Soc. 2011, 133, 16572-16580. [CrossRef]

7. Ren, X.-B.; Chen, M.; Qian, D.-J. Pd(II)-Mediated Triad Multilayers with Zinc Tetrapyridylporphyrin and Pyridine-Functionalized $\mathrm{Nano}-\mathrm{TiO}_{2}$ as Linkers: Assembly, Characterization, and Photocatalytic Properties. Langmuir 2012, 28, 7711-7719. [CrossRef]

8. Duan, M.; Li, J.; Mele, G.; Wang, C.; Lü, X.; Vasapollo, G.; Zhang, F. Photocatalytic Activity of Novel Tin Porphyrin/ $\mathrm{TiO}_{2}$ Based Composites. J. Phys. Chem. C 2010, 114, 7857-7862. [CrossRef]

9. Li, D.; Dong, W.; Sun, S.; Shi, Z.; Feng, S. Photocatalytic Degradation of Acid Chrome Blue K with Porphyrin-Sensitized $\mathrm{TiO}_{2}$ under Visible Light. J. Phys. Chem. C 2008, 112, 14878-14882. [CrossRef]

10. Mele, G.; del Sole, R.; Vasapollo, G.; Marcì, G.; Garcìa-Lòpez, E.; Palmisano, L.; Coronado, J.M.; Hernández-Alonso, M.D.; Malitesta, C.; Guascito, M.R. TRMC, XPS, and EPR Characterizations of Polycrystalline $\mathrm{TiO}_{2}$ Porphyrin Impregnated Powders and Their Catalytic Activity for 4-Nitrophenol Photodegradation in Aqueous Suspension. J. Phys. Chem. B 2005, 109, 12347-12352. [CrossRef]

11. Meng, Z.-D.; Zhu, L.; Choi, J.-G.; Chen, M.-L.; Oh, W.-C. Effect of Pt treated fullerene/ $\mathrm{TiO}_{2}$ on the photocatalytic degradation of MO under visible light. J. Mater. Chem. 2011, 21, 7596. [CrossRef]

12. Krishna, V.; Noguchi, N.; Koopman, B.; Moudgil, B. Enhancement of titanium dioxide photocatalysis by water-soluble fullerenes. J. Colloid Interface Sci. 2006, 304, 166-171. [CrossRef] [PubMed]

13. Krishna, V.; Yanes, D.; Imaram, W.; Angerhofer, A.; Koopman, B.; Moudgil, B. Mechanism of enhanced photocatalysis with polyhydroxy fullerenes. Appl. Catal. B Environ. 2008, 79, 376-381. [CrossRef] 
14. Lin, J.; Zong, R.; Zhou, M.; Zhu, Y. Photoelectric catalytic degradation of methylene blue by $\mathrm{C}_{60}$-modified $\mathrm{TiO}_{2}$ nanotube array. Appl. Catal. B Environ. 2009, 89, 425-431. [CrossRef]

15. Apostolopoulou, V.; Vakros, J.; Kordulis, C.; Lycourghiotis, A. Preparation and characterization of [60] fullerene nanoparticles supported on titania used as a photocatalyst. Colloids Surf. Physicochem. Eng. Asp. 2009, 349, 189-194. [CrossRef]

16. Oh, W.-C.; Jung, A.-R.; Ko, W.-B. Preparation of Fullerene $/ \mathrm{TiO}_{2}$ Composite and Its Photocatalytic Effect. J. Ind. Eng. Chem. 2007, 13, 1208-1214.

17. Katsumata, K.; Matsushita, N.; Okada, K. Preparation of $\mathrm{TiO}_{2}$-Fullerene Composites and Their Photocatalytic Activity under Visible Light. Int. J. Photoenergy 2012, 2012, 256096. [CrossRef]

18. Oh, W.-C.; Zhang, F.-J.; Meng, Z.-D.; Zhang, K. Relative Photonic Properties of Fe/ $\mathrm{TiO}_{2}-\mathrm{Nanocarbon}$ Catalysts for Degradation of MB Solution under Visible Light. Bull. Korean Chem. Soc. 2010, 31, 1128-1134. [CrossRef]

19. Yang, M.-Q.; Zhang, N.; Xu, Y.-J. Synthesis of Fullerene-, Carbon Nanotube--, and Graphene-TiO 2 Nanocomposite Photocatalysts for Selective Oxidation: A Comparative Study. ACS Appl. Mater. Interfaces 2013, 5, 1156-1164. [CrossRef]

20. Zhao, Z.; Ozoemena, K.I.; Maree, D.M.; Nyokong, T. Synthesis and electrochemical studies of a covalently linked cobalt(II) phthalocyanine-cobalt(II) porphyrin conjugate. Dalton Trans. 2005, 7, 1241-1248. [CrossRef]

21. Kadish, K.M.; van Caemelbecke, E. Electrochemistry of porphyrins and related macrocycles. J. Solid State Electrochem. 2003, 7, 254-258. [CrossRef]

22. Fernández-García, M.; Wang, X.; Belver, C.; Hanson, J.C.; Rodriguez, J.A. Anatase-TiO 2 Nanomaterials: Morphological/Size Dependence of the Crystallization and Phase Behavior Phenomena. J. Phys. Chem. C 2007, 111, 674-682. [CrossRef]

23. Burgos, M.; Langlet, M. The sol-gel transformation of TIPT coatings: A FTIR study. Thin Solid Films 1999, 349, 19-23. [CrossRef]

24. Zhao, D.; Peng, T.; Liu, M.; Lu, L.; Cai, P. Fabrication, characterization and photocatalytic activity of $\mathrm{Gd}^{3+}$-doped titania nanoparticles with mesostructured. Microporous Mesoporous Mater. 2008, 114, 166-174. [CrossRef]

25. Regulska, E.; Karpinska, J. Investigation of Photocatalytic Activity of $\mathrm{C}_{60} / \mathrm{TiO}_{2}$ Nanocomposites Produced by Evaporation Drying Method. Pol. J. Environ. Stud. 2014, 23, 2175-2182.

26. Regulska, E.; Karpinska, J. Investigation of novel material for effective photodegradation of bezafibrate in aqueous samples. Environ. Sci. Pollut. Res. 2014, 21, 5242-5248. [CrossRef] [PubMed]

27. Su, C.; Hong, B.-Y.; Tseng, C.-M. Sol-gel preparation and photocatalysis of titanium dioxide. Catal. Today 2004, 96, 119-126. [CrossRef]

28. Bahnemann, D.; Henglein, A.; Spanhel, L. Detection of the intermediates of colloidal $\mathrm{TiO}_{2}$-catalysed photoreactions. Faraday Discuss. Chem. Soc. 1984, 78, 151-163. [CrossRef]

29. Chung, I.; Lee, B.; He, J.; Chang, R.P.H.; Kanatzidis, M.G. All-solid-state dye-sensitized solar cells with high efficiency. Nature 2012, 485, 486-489. [CrossRef]

30. Dz. U 2014 poz. 1482-Regulation of the Minister of the Environment on the Method of Classifying the Status of Uniform Bodies of Surface Water and Environmental Quality Standards for Priority Substances (Journal of Laws, Item 1482, 2014); 2014.

31. Dz. U 2014 poz. 1800-Regulation of the Minister of the Environment on the Conditions to Be Met When Discharging Sewage to Waters or to the Soil and on Substances of Particular Adverse Impact on the Water Environment (Journal of Laws, Item 1800, 2014); 2014.

32. Mariquit, E.G.; Salim, C.; Hinode, H. The Role of Calcium Ions in the Photocatalytic Oxidation of Humic Acid at Neutral pH. Ann. N. Y. Acad. Sci. 2008, 1140, 389-393. [CrossRef]

33. Jiang, Y.; Luo, Y.; Lu, Z.; Huo, P.; Xing, W.; He, M.; Li, J.; Yan, Y. Influence of Inorganic Ions and pH on the Photodegradation of 1-Methylimidazole-2-thiol with $\mathrm{TiO}_{2}$ Photocatalyst Based on Magnetic Multi-walled Carbon Nanotubes. Bull. Korean Chem. Soc. 2014, 35, 76-82. [CrossRef]

34. Hashimoto, K.; Irie, H.; Fujishima, A. $\mathrm{TiO}_{2}$ Photocatalysis: A Historical Overview and Future Prospects. Jpn. J. Appl. Phys. 2005, 44, 8269-8285. [CrossRef] 
35. Martínez-Zapata, M.; Aristizábal, C.; Peñuela, G. Photodegradation of the endocrine-disrupting chemicals 4n-nonylphenol and triclosan by simulated solar UV irradiation in aqueous solutions with Fe(III) and in the absence/presence of humic acids. J. Photochem. Photobiol. Chem. 2013, 251, 41-49. [CrossRef]

36. Canonica, S. Oxidation of Aquatic Organic Contaminants Induced by Excited Triplet States. Chim. Int. J. Chem. 2007, 61, 641-644. [CrossRef]

Sample Availability: Samples of the compounds are available from E.R.

(C) 2019 by the authors. Licensee MDPI, Basel, Switzerland. This article is an open access article distributed under the terms and conditions of the Creative Commons Attribution (CC BY) license (http://creativecommons.org/licenses/by/4.0/). 